\title{
BRIEF CONSIDERATIONS ON THE EUROPEAN LEGISLATIVE PROCEDURES, WITH PARTICULAR REFERENCE TO PASSERELLE CLAUSES
}

\author{
M. PĂTRĂUȘ, D. D. PĂTRĂUṢ
}

\section{Mihaela Pătrăus}

Faculty of Law, Department of Law

University of Oradea, Oradea, Romania

*Correspondence: Mihaela Pătrăuș, University of Oradea, General Magheru St., Oradea, Romania

E-mail: mihaelapatraus@yahoo.com

\section{Darius-Dennis Pătrăuș}

Faculty of Law Cluj-Napoca

Babeș-Bolyai University of Cluj-Napoca

*Correspondence: Mihaela Pătrăuş, University of Oradea, General Magheru St., Oradea, Romania

E-mail: darius_patraus@ @otmail.com

\section{ABSTRACT:}

The Lisbon Treaty in order to strengthen the EU's capacity to decide, to act and to ensure the legitimacy of decisions taken at the same time, reformed the decision-making process of the EU, particularly by changing the legislative procedures in force.

Among the novelties of the Lisbon Treaty, we must mention the passerelle clauses, which according to the ordinary legislative procedure will be generalized, under certain conditions, in areas which were initially outside its scope.

The treaty nominates two types of passerelle clauses: the general passerelle clause which applies to all European policies and the enabling of this clause will be authorized by a decision of the European Council, acting unanimously; the passerelle clauses specific to certain European policies (MFF, Common Security and Defence Policy, judicial cooperation regarding the family rights- this specific clause is the only one explaining which national parliaments keep their right to oppose; cooperation is strengthened in the areas governed by unanimity or by a special legislative procedure, social affairs, environmental ).

The flexibility introduced through a significant number of passerelle clauses in the Lisbon Treaty allows adjustment of the EU quickly and efficiently, depending on punctual developments, without neglecting the guarantees on the sovereignty of member states.

KEYWORDS: LISBON TREATY, PASSERELLE CLAUSES, THE GENERAL PASSERELLE CLAUSE, THE PASSERELLE CLAUSES SPECIFIC, UNION INSTITUTIONS.

\section{OVERVIEW}

The European construction is based on the EU Member States' willingness to work together on common interests. This led to the belief that in some areas the expected results can be achieved only at European level through common policies developed and adopted by the institutions of the EU. ${ }^{1}$

\footnotetext{
${ }^{1}$ M. Profiroiu, I. Popescu - European Politics, Economic Publishing House, Bucharest, 2003, p. 13-14.
} 
The Lisbon Treaty ${ }^{2}$ aimed at strengthening the capacity of decision and acting of the EU whilst guaranteeing the legitimacy of decisions taken, reforming especially by amending the legislative procedures in force. ${ }^{3}$

Art. 289 par. 1 and 2 of the Treaty on the Functioning of the EU have introduced two types of legislative procedures - ordinary and special. At the same time, the Treaty of Lisbon has introduced the passerelle clauses which, according to the ordinary legislative procedure should be generalized, under certain conditions, in areas that were initially outside field of application. $^{4}$

\section{ORDINARY LEGISLATIVE PROCEDURE}

The ordinary legislative procedure replaces the former co-decision procedure, which over time has become the most commonly used procedure.

This procedure is the most legitimate from a democratic point of view.

Art. 294 TFEU governing the ordinary legislative procedure requires the adoption of an act jointly by the European Parliament and the Council, on a proposal from the Commission. $^{5}$

The Lisbon Treaty confirms the trend of the widespread use of this procedure, but changes its name and determines that it is a common law procedure. Moreover, extending the ordinary legislative procedure to new areas of union policy.

Under this procedure occurs a revaluation of the position of the European Parliament from a secondary legislative body into a mainly legislative body on par with the Council since the European Parliament has a right of veto in adopting the legislative act that cannot be removed by the Council unilaterally. ${ }^{6}$

The detailed application of the ordinary legislative procedure are identical to those of the co-decision procedure, being extensively described in art.294 content TFEU.

From the structure of art. 294 TFEU results that the first step is to send simultaneously proposals to the Commission, the European Parliament and the Council, all three being equal in the decision-making process.

The procedure is complex and is structured in three readings, steps being summarized in the content of art. 294 TFEU.

Thus, at first reading ${ }^{7}$, the European Parliament is the first to adopt its position and sent it to the Council, which in case they approve the Parliament's position, the act is adopted in the wording which corresponds to the European Parliament's position and in case they do not approve the Parliament's position, the Council will adopt its own position and send it to the European Parliament, informing it on the reasons. In this case, it will proceed to a second reading.

The Commission must clarify its position and inform the European Parliament. At the second reading, if, within three months of such communication, the European Parliament approves the Council's position from the first reading or does not pronounce anything, the act is deemed adopted, according to the position expressed by the Council. If the European Parliament rejects with a majority of its component members, the Council's position from the first reading, the act is deemed as not adopted. When the European Parliament proposes, with a majority of its component members, amendments to the Council's position, the text is

\footnotetext{
${ }^{2}$ The Reform Treaty signed in Lisbon at 13.12.2007 and entered into force at 1.12.2009.

${ }^{3}$ Previously, there were over 52 legislative procedures in the union law, each used according to legal rules that regulated the development and the adoption of Community legislation (cooperation procedure, the co-decision, approvals, etc.). For more details F. Gyula, Institutional Law of EU, Hamangiu Publishing House, Bucharest, 2012, p.188.

${ }^{4}$ I. Gâlea - EU Treaty. Comments and explanations, C.H. Beck Publishing House, Bucharest, 2012, p. XIX.

${ }^{5}$ Art. 294 para. 2 TFEU.

${ }^{6}$ F. Gyula, op. cit., p. 190.

${ }^{7}$ Art. 294 para. 3-6 TFEU.
} 
submitted to the Council and the Commission, the latter gives its opinion on these amendments. For its part, the Council has a period of three months from the receipt of the modifications made by the European Parliament and with qualified majority can approve all the changes, the act being considered adopted, otherwise the procedure continues, the conciliation Committee being summoned by the Presidents of the Council and European Parliament.

The role of the Committee referred to in art. 293 TFEU is highlighted in the second reading, because if the proposed amendments have received a negative opinion from the Council, it must decide by unanimity and if it's positive, with qualified majority.

Conciliation $^{8}$ is performed by the Conciliation Committee composed of members of the Council or their representatives and an equal number of members of the European Parliament and has the task of reaching an agreement on a joint text within six weeks. The decision is taken by qualified majority of the Council members, not majority of MEPs and The Commission participates in and take initiatives to promote an approach between the positions of the EU. At the end of the six weeks, if they do not reach an agreement, the act is deemed rejected.

At the third reading ${ }^{9}$ there is an opportunity to make amendments, the European Parliament and Council may approve within the six weeks the joint text resulting from conciliation.

If one of the institutions rejects the joint or does not approve it, the act is deemed rejected.

An element of flexibility will be applied horizontally concerning the deadlines of three months and six weeks referred to in this procedure, that they may be extended at most one month or two weeks at the initiative of the European Parliament or the Council. ${ }^{10}$

\section{SPECIAL LEGISLATIVE PROCEDURES}

Special legislative procedures replace the former procedures of consultation, cooperation and assent. The objective is to simplify the decision-making process of the EU, making it clearer and more effective. As the name indicates, these procedures derogate from the ordinary legislative procedures and therefore constitute exceptions.

In special legislative procedures, the EU Council is, in practice, the sole legislator. The European Parliament is simply associated with the procedure. Its role is thus limited to consultation or approval, as applicable.

Unlike the ordinary legislative procedures, the Treaty on the Functioning of the European Union does not provide a precise description of special legislative procedures. Special legislative rules of procedure are therefore defined on an ad hoc basis by the Articles of the Treaty on European Union and the Treaty on the Functioning of the European Union, which provides their implementation

\section{PASSERELle ClaUSES ${ }^{11}$}

The Treaty of Lisbon has introduced passerelle clauses to be able to apply the ordinary legislative procedures to areas in which treaties have established a special legislative procedure. Moreover, these clauses allow qualified majority voting to be applied to acts which are to be adopted unanimously.

There are two types of passerelle clause:

\footnotetext{
${ }^{8}$ Art. 294 para. 10-12 TFEU.

9 Art. 294 para. 13-14 TFEU.

${ }^{10}$ This rule was introduced by the Treaty of Amsterdam and was accompanied by a declaration annexed to the Final Act, stating that the institutions will strictly respect deadlines and will only resort to the temporal extension when it is absolutely necessary.

${ }^{11} \underline{\mathrm{http}}$ //europa.eu/legislation_summaries/institutional_affairs/treaties/lisbon_treaty/ai0 016_en.htm; date: 29.04.2015; hour: 19:38.
} 
-the general passerelle clause which applies to all European policies; the activation of this clause must be authorized by a decision of the European Council, acting unanimously. Passerelle clause constitutes a revision procedure of the EU Treaties, as shown in art.48 paragraph 7 TEU.

This clause applies in two situations: a) where the Treaties provide that an act be adopted unanimously by the Council, the European Council may decide to authorize the Council to adopt the decision by qualified majority, except for decisions with military implications or defence; $\quad$ b) where the Treaties provide that an act is to be adopted in accordance with a special legislative procedure, the European Council may decide to authorize such an act adopted under the ordinary legislative procedure.

In both cases, the European Council may adopt the decision unanimously after obtaining the consent of the European Parliament. However, it is noted that national parliaments have a right to object and prevent the activation of the general passerelle clause.

- specific passerelle clauses with respect to certain European policies

The specific passerelle clauses have certain features of procedure regarding the general passerelle clause. For example, national parliaments have generally a right to object, this right is granted to them by the general clause. In other cases, the application of certain specific clause may be authorized by a decision of the Council, and not the European Council as is the case for the general clause. Therefore, the rules for applying the specific terms vary from case to case and are described in the articles of treaties providing for their application.

There are six specific passerelle clauses to be applied to: 1) Multiannual financial framework (art. 312 TFEU); 2) Common Security and Defence Policy (art. 31 TEU); 3) Judicial cooperation concerning family law (art. 81 TEU). This specific clause is the only clause regarding which national Parliaments retain the right to object; 4) Enhanced cooperation in the areas covered by unanimity or a special legislative procedure (art. 333 TFEU); 5) Social Affairs (art. 153 TEU); 6) Environmental (art. 192 of the TEU).

\section{MULTIANNUAL FINANCIAL FRAMEWORK ${ }^{12}$}

1. The multiannual financial framework shall ensure that Union expenditure develop in an orderly manner and within its own resources. It is adopted for a period of at least five years. The annual budget of the Union respects the multiannual financial framework.

2. The Council, acting in accordance with a special legislative procedure, adopts a regulation laying down the multiannual financial frame work. The Council shall act unanimously after the approval of Parliament, which shall act by a majority of its component members. The European Council can unanimously adopt a decision authorizing the Council to act by qualified majority when adopting the regulation of the Council under the first paragraph.

3. The financial framework shall determine the amounts of the annual limits on commitment appropriations by category of expenditure and of the annual limits on payment appropriations. The categories of expenditure, limited in number, shall correspond to the main sectors of Union activities. The financial framework shall lay down any other provisions required for the annual budgetary procedure to run smoothly.

4. If the Council Regulation establishing a new financial framework has been adopted at the end of the previous financial framework, the limits and other provisions corresponding to the last year of that framework shall be extended until the adoption of this act.

\footnotetext{
${ }^{12} \mathrm{http}$ ///www.lisbon-treaty.org/wcm/the-lisbon-treaty/treaty-on-the-functioning-of-theeuropean-union-and-comments/part-6-institutional-and-financial-provisions/title-2financial-provisions/chapter-2-the-multiannual-financial-framework/632-article-
} 312.html; date: 30.04.2015; hour: 12:09. 
5. Throughout the procedure leading to the adoption of the financial framework, the European Parliament, the Council and the Commission shall take all necessary measures to facilitate the adoption.

This multiannual spending program, which reflects from a financial point of view, the EU's policy priorities, establishing expenditure ceilings for a certain period of time, from the perspective of the vote, following the insertion of the special passerelle clause, allows the transfer from the rule of the unanimity to that of the majority, leading to a greater flexibility in defining the European financial framework.

\section{COMMON SECURITY AND DEFENCE POLICY ${ }^{13}$}

The Lisbon Treaty seeks to strengthen the role of the European Union (EU) on international level. The reforms introduced by the Treaty aim to make the Common Security and Defence Policy (CFSP) of the EU more coherent and to increase visibility.

In this sense, the Treaty of Lisbon introduces two major innovations: creating High Representative of the Union for Foreign Affairs and Security Policy and the European External Action Service; the development of common security and defence policy.

The Lisbon Treaty introduces a special passerelle clause regarding this segment, which allows the European Council to decide, by unanimous vote, the extension of qualified majority voting in CFSP.

Alongside these two innovations, the Treaty of Lisbon also introduces other less important changes, particularly regarding procedures for implementing the CFSP.

\section{JUDICIAL COOPERATION REGARDING FAMILY LAW ${ }^{14}$}

1. The Union shall develop judicial cooperation in civil matters having cross-border implications, based on the principle of mutual recognition of judgments and judicial decisions and court settlements. Such cooperation may include the adoption of measures for the approximation of the laws and regulations of the Member States.

2. For the purposes of paragraph 1, the European Parliament and the Council, acting in accordance with the ordinary legislative procedure, shall adopt measures, particularly when necessary for the proper functioning of the internal market, aimed at ensuring:(a) the mutual recognition between Member States of judgments and judicial and extrajudicial decisions;(b) cross-border service of judicial and extrajudicial documents; $(c)$ the compatibility of the rules applicable in the Member States concerning conflict of laws and of jurisdiction; $(d)$ cooperation in the taking of evidence; $(e)$ effective access to justice; $(f)$ the elimination of obstacles to the good functioning of civil proceedings, if necessary by promoting the compatibility of rules on civil procedure applicable in the Member States; $(\mathrm{g})$ the development of alternative methods of dispute resolution; $(h)$ support the training of magistrates and judicial personnel.

3. Notwithstanding the paragraph 2, measures concerning family law with crossborder implications shall be established by the Council, acting in accordance with a special legislative procedure. The Council shall act unanimously after consulting the European Parliament.

On a proposal from the Commission, may adopt a decision determining those aspects of family law with cross-border implications which may be the subject of acts adopted by the

\footnotetext{
${ }^{13}$ http://europa.eu/legislation_summaries/institutional_affairs/treaties/lisbon_treaty/ai0 025 en.htm; date: 30.04.2015; hour: 12:39.

${ }^{14} \mathrm{http}$ ://www.lisbon-treaty.org/wcm/the-lisbon-treaty/treaty-on-the-functioning-of-theeuropean-union-and-comments/part-3-union-policies-and-internal-actions/title-v-areaof-freedom-security-and-justice/chapter-3-judicial-cooperation-in-civil-matters/349article-81.html; date: 30.04.2015; hour: 13:15.
} 
ordinary legislative procedure. The Council shall act unanimously after consulting the European Parliament.

The proposal referred to in the second subparagraph shall be notified to national parliaments. If a national parliament within six months from the date of such notification, not the decision. In the absence of opposition, the Council may adopt the decision.

The Lisbon Treaty increases the efficiency of the decision-making process in this area, by extending the vote to qualified majority and by making this procedure, the usual and standard voting procedure, with a limited number of exceptions, as highlighted above.

\section{ENHANCED COOPERATION IN THE AREAS COVERED BY UNANIMITY OR A SPECIAL LEGISLATIVE PROCEDURE ${ }^{15}$}

1. Where a provision of the Treaties which may be applied in the context of enhanced cooperation stipulates that the Council shall act unanimously, the Council, acting unanimously in accordance with the conditions laid down in art. 330, may adopt a decision stipulating that a qualified majority.

2. Where a provision of the Treaties which may be applied in the context of enhanced cooperation stipulates that the Council acts in accordance with a special legislative procedure, the Council, acting unanimously in accordance with the requirements of art. 330 may adopt a decision stipulating that it will act under the ordinary legislative procedure. It shall act after consulting the European Parliament.

3. Paragraphs 1 and 2 shall not apply to decisions with military or defence implications.

\section{SOCIAL AFFAIRS ${ }^{16}$}

1. In order to achieve the objectives of art.151, the Union shall support and complement Member States' action in the following areas:(a) improvement in particular of the working environment to protect the health and safety of workers; $(b)$ working conditions; (c) social security and social protection of workers; (d) the protection of workers if the employment contract is terminated;(e) the information and consultation of workers; $(f)$ representation and collective defence of the interests of workers and employers, including codetermination, subject to paragraph 5; $(\mathrm{g})$ conditions of employment for third country nationals legally residing in Union territory; $(h)$ the integration of persons excluded from the labour market, without prejudice to art. 166;(i) equality between men and women with regard to labour market opportunities and treatment at work; $(j)$ the combating of social exclusion; $(k)$ the modernization of social protection systems without prejudice to point (c).

2. To this end, the European Parliament and the Council. :(a) may adopt measures designed to encourage cooperation between Member States through initiatives aimed at improving knowledge, developing exchanges of information and best practices, promoting innovative approaches and evaluating experiences, excluding any harmonization of the laws and regulations of the Member States;(b) may, in the areas referred to in paragraph $1(a)$ (i), by means of directives, minimum requirements for gradual implementation, having regard to the conditions and technical rules in each Member State. Such directives are to avoid imposing administrative, financial and legal in a way which would hold back the creation and development of small and medium enterprises.

\footnotetext{
${ }^{15} \mathrm{http}$ ://europa.eu/legislation_summaries/institutional_affairs/treaties/lisbon treaty/ai0 016_en.htm; date: 30.04.2015; hour: 14:22.

${ }^{16} \mathrm{http}: / / \mathrm{www}$. lisbon-treaty.org/wcm/the-lisbon-treaty/treaty-on-the-functioning-of-theeuropean-union-and-comments/part-3-union-policies-and-internal-actions/title-Xsocial-policy/420-article-153.html; , date: 30.04.2015; hour: 15:02.
} 
The European Parliament and the Council shall act in accordance with the ordinary legislative procedure after consulting the Economic and Social Committee and the Committee of the Regions.

The matters referred to in paragraph $1(c),(d),(f)$ and $(g)$, the Council decided unanimously in accordance with a special legislative procedure, after consulting the European Parliament and the said Committees.

The Council, acting unanimously on a proposal from the Commission, after consulting the European Parliament, may decide that the ordinary legislative procedure applicable to paragraph $1(d),(f)$ and $(g)$.

3. A Member State may entrust management and labour, at their joint request, with the implementation of directives adopted in accordance with paragraph 2, or, where appropriate, the implementation of a Council decision taken in accordance with art. 155.

In this case, it shall ensure that, no later than the date on which must be transposed or implemented a directive or a decision, the social partners have introduced the necessary measures by agreement, the Member States concerned must take all necessary measures to enable the any time to be able to guarantee the results imposed by that directive or decision.

4. The provisions adopted pursuant to this Article: not affect the right of Member States to define the fundamental principles of their social security systems and must not significantly affect the financial equilibrium thereof; I cannot prevent a Member State from maintaining or introducing more stringent protective measures compatible with the Treaties.

5. This Article shall not apply to pay, the right of association, the right to strike or the right to lock-out.

The Treaty of Lisbon strengthens the social dimension of Europe, including in terms of policy content and means of decision making. The extension of qualified majority voting to social services for migrant workers in the EU seeks to facilitate for them the consideration of all these periods of employment, in order to receive the benefits that both the migrant workers and their families are entitled to. Where a Member State considers that such a measure is in contradiction with important aspects of its national social security system, the State may require the Commission to prepare a new project or may make an "appeal" to the European Council.

The unanimity rule is retained on decisions in this matter, on certain issues, mentioned above.

\section{ENVIRONMENTAL ${ }^{17}$}

1. The European Parliament and the Council, acting in accordance with the ordinary legislative procedure and after consulting the Economic and Social Committee and the Committee of the Regions, shall decide on the measures to be taken by the Union in order to achieve the objectives of art. 191.

2. By way of derogation from the decision referred to in paragraph 1 and without prejudice to art. 114, the Council, acting unanimously in accordance with a special legislative procedure and after consulting the European Parliament, the European Economic and Social Committee and the Committee of the Regions, shall adopt:(a) provisions primarily of a fiscal nature;(b) measures affecting- spatial, quantitative management of water resources or affecting, directly or indirectly, the availability of those resources, land use, with the exception of waste management;(c) measures significantly affecting a Member State choice between different energy sources and the general structure of its energy supply.

The Council, acting unanimously on a proposal from the Commission and after consulting the European Parliament, the European Economic and Social Committee and the

\footnotetext{
${ }^{17} \mathrm{http}$ ://www.lisbon-treaty.org/wcm/the-lisbon-treaty/treaty-on-the-functioning-of-theeuropean-union-and-comments/part-3-union-policies-and-internal-actions/title-Xxenvironment-climate-change/480-article-192.html, date: 30.04.2015; hour: 15:27
} 
Committee of the Regions, may make the ordinary legislative procedure applicable to the matters referred to in the first paragraph.

3. General action programs setting out priority objectives to be attained shall be adopted by the European Parliament and the Council, acting in accordance with the ordinary legislative procedure and after consulting the Economic and Social Committee and the Committee of the Regions.

The measures necessary for the implementation of these programs shall be adopted in accordance with the conditions set out in paragraph 1 or 2, as the case may be.

4. Without prejudice to certain measures adopted by the Union, Member States shall finance and implement the environment policy.

5. Without prejudice to the principle that the polluter should pay, if a measure based on paragraph 1 involves costs deemed disproportionate for the public authorities of a Member State, such measure shall lay down appropriate form: temporary derogations and / or financial support from the Cohesion Fund set up under art. 177. ${ }^{18}$

The EU action regarding environment protection is based on the need to protect and improve the environment. The Lisbon Treaty recognizes climate change as one of the most important global challenge and identifies the measures through which the EU can respond to it.

In order to achieve the objectives of environmental protection, the treaty introduces a special passerelle clause in art. 192 paragraph 2, stating that through unanimous vote from the Council, on a proposal from the Commission and in consultation with the European Parliament, the European Economic and the Social Committee, it is possible to vote on qualified majority in these areas.

\section{CONCLUSIONS}

Transformations and deep changes occurring in the European construction, the appearance and essence, quantitative and qualitative, of substance and form were impacted positively by allowing major variations regarding the role and powers of the institutions of union arrangements exercising skills correspondent reaching decision-making procedures and judicial review. ${ }^{19}$

These changes in the European institutional referring to the decision-making procedure we appreciate as being favourable to the reform process's rate and able to objectified conclusion reached by the Laeken Declaration ${ }^{20}$ that "U.E. It is a success story. "

Flexibility introduced by an important number of clauses in the Treaty of Lisbon walkways allow adjustments to the EU Framework quickly and efficiently, depending on developments punctual, without neglecting the guarantees on the sovereignty of member states.

However, we consider that union efforts institutions expressed these innovative formulations, should be complemented by actions of the Member States responsible.

\footnotetext{
${ }^{18}$ Art. 177 TFEU.

19 With regard to judicial review, see A.Tizzano, Some considerations on the Court of Justice, Romanian Journal of European Law no. 6/2012, Publisher Wolters Kluwer, Bucharest, p. 28.

20 The Declaration regarding the future of the E.U., December 2001 cit. by J, -C. Piris, The Lisbon Treaty, A Legal and Political Analysis, Cambridge University Press, 2010, p.12
} 


\section{BIBLIOGRAPHY}

1. M. Profiroiu, I. Popescu, European Politics, Publisher Economica, Bucharest, 2003.

2. F. Gyula, Institutional Law of EU, Hamangiu Publishing House, Bucharest, 2012.

3. Gâlea, EU Treaty. Comments and explanations, C.H. Beck Publishing House, Bucharest, 2012.

4. J,-C. Piris, The Lisabon Treaty, A Legal and Political Analysis, Cambridge University Press, 2010.

5. http://europa.eu/ legislation_summaries/institutional_affairs/treaties/lisbon_treaty

6. http://www.lisbon-treaty.org/wcm/the-lisbon-treaty/treaty-on-the-functioning-of-theeuropean-union-and-comments.

7. The Reform Treaty signed in Lisbon at 13.12.2007 and entered into force at 1.12.2009. 